European journal of American studies

\title{
"A Tract in Fiction": Woman Suffrage Literature and the Struggle for the Vote
}

Claire Delahaye

\section{OpenEdition}

\section{Journals}

\section{Electronic version}

URL: https://journals.openedition.org/ejas/11421

DOI: 10.4000/ejas. 11421

ISSN: 1991-9336

Publisher

European Association for American Studies

Electronic reference

Claire Delahaye, "'A Tract in Fiction": Woman Suffrage Literature and the Struggle for the Vote",

European journal of American studies [Online], 11-1 | 2016, document 3, Online since 02 June 2016 connection on 08 July 2021. URL: http://journals.openedition.org/ejas/11421 ; DOI: https://doi.org/ 10.4000/ejas. 11421

This text was automatically generated on 8 July 2021 .

Creative Commons License 


\title{
"A Tract in Fiction": Woman Suffrage Literature and the Struggle for the Vote
}

\author{
Claire Delahaye
}

1 In November 1907, The New York Times published a lengthy review of Elizabeth Robin's new novel The Convert, the story of a woman becoming a pleader for the suffrage cause in London, described by the title as a "Tract in Fiction." ${ }^{\prime i}$ The newspaper lambasted the novel for its political contenti: "The romancer who writes for a purpose and who uses the art of fiction merely as a medium for political propaganda cannot expect work so produced to measure up to standards set by the impartial canons of literature" ("Noted Novelist's Plea for Women: Stirring Appeal for the Suffrage in Elizabeth Robin's Book, 'The Convert'-A Tract in Fiction"). The scathing review goes on criticizing the novelist for merging "the creative sense of the artist too far in the rhetorical enthusiasm of the doctrinaire." The references to "propaganda" and to the author as a "doctrinaire" reprove the proselytical nature of the novel and its dogmatism. Does this review simply reflect the political stance of The New York Times or is it right in its assessment that suffrage dogmatism exploited art and produced works lacking any literary quality? This issue has been dealt with differently by scholars. For instance, in Declarations of Independence: Women and Political Power in Nineteenth-Century American Fiction (1990), Barbara Bardes and Suzanne Gossett looked at several ways that women's political participation influenced American literature but dismissed what they call "pro-woman's rights novels" as "little more than fictionalized didactic tracts" (180) and reduced them to a single theory that the vote ought to be given to women. In Romancing the Vote (2006), Leslie Petty worked to rehabilitate suffrage novels and their 
content, trying not to idealize the feminist message in the books and also not to dismiss them because of their race and class bias (2).

2 The fact that suffrage literature was discarded as mere propaganda is in itself problematic, as it could be argued that it is specifically because of its propaganda that it is valuable. Indeed, it pertained to the assertion and legitimation of suffragists' political power and contributed to the creation of suffragists' culture. The spreading of suffragists' ideas through fiction is a testimony to "the progressive faith in the power of print" and the "belief in the power of fiction to transform society" (Harker 13-14). The present article will not engage in a debate on the aesthetic value of this literature but will focus on suffrage literature as political texts and argue that aesthetics and politics are inseparable in the assertion of the possibility of woman's political power. Woman suffrage literary works, whose vast and diverse productions included novels, short stories, poetry, songs and plays, deserve a closer look. Starting with Laura Curtis Bullard'sii popular novel Christine, or Woman's Trials and Triumphs (1856), in which a young woman becomes a woman's rights lecturer, American suffragists used creative writing to promote the cause until the passage of the $19^{\text {th }}$ amendment in 1920 . Suffrage literary writings gained momentum in the 1910 s as the growing market for stories to be published that would interest female readership played a part in the development of a print culture. This article will focus on this last period of the suffrage struggle.

3 This essay aims at contributing to the argument made by Mary Chapman, who analyzed suffragists' material as both politically modern

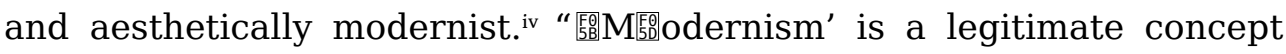
broadly signifying a paradigmatic shift, a major revolt, beginning in the mid- and late nineteenth century, against the prevalent literary and aesthetic traditions of the Western world" (Eysteinsson 2). According to Chapman, the production and circulation of printed materials coincided with the emergence of literary modernism (4), and suffragists contributed to the "emergence of the 'modern quoting poem' and other examples of modernist intertextuality" (12). This study specifically addresses how the issues such as modernism can be understood as a shift of power. What is the role of suffrage literature in this negotiation of power shifting? How does it illuminate historians' understanding of the movement?

4 The texts written by suffragists asserted women's political power and fiction inspired by woman suffrage activism attested to women's growing power in the American public sphere. This articulation between art and politics is of particular significance to the historian as it can give insight into suffragists' strategies to win the vote and into the context of the movement in relation to the issue of ideas and representations. Suffrage literary productions helped to negotiate conditions of existence and were forms of empowerment, resting on the belief that literature could change the world, from the perspective of women as a subordinate group. This conviction attests to suffragists' 
confidence in the power of words and it provides a "missing piece" in the history of the suffrage movement's relation to popular culture. ${ }^{v}$

5 The following analysis will explore some aspects of woman suffragists' literary productions in relation to women's political power: the way these writings were used as political tools, their explorations of new literary forms and their relationship to their environment. For this article, I used some of the works that are available as reprints and reviews of suffrage literature published in newspapers at the time, to see how these works were discussed. The authors whose works I have selected were very popular and were involved in the suffrage movement. ${ }^{\text {i }}$ These writers used their pen to support the cause and earned their living as professional writers.

\section{A War of Words: Suffrage Literature as Political Tool}

6 Suffragists used different types of writings to promote women's right to vote. Essays, articles, histories, biographies, letters, and pamphlets were among the forms chosen by women to appeal to the American public opinion. But female suffragists also used fiction to promote movements of reform, which contributed "to the creation and continued viability of these movements" (Petty 2). Suffrage fiction portrayed existing reform communities, individual journeys that could serve as models for readers, who could join movements afterwards (Petty 2). It is very difficult to determine what impact fictional portrayals of suffragists may have had on the movement yet "one cannot dispute that suffragists and other reformers believed in their capacity to enrich and expand their movements" (Petty 6). vii As noted by Tebbel, throughout the 1910s, the number of books on the woman question was growing steadily (31). viii From the point of view of female suffragists, literature may have seemed as a less threatening way to participate in politics as writing could be contemplated as an "extension of female influence in the domestic realm" (Chapman 6), all the more so since there had been famous precedents, such as Susan Warner, Harriet Beecher Stowe, Helen Hunt Jackson or Kate Chopin, to name just a few. ${ }^{\text {ix }}$ Women finding their own political voice was thus a theme, but the very act of writing itself partook of women's necessity to seek their own means of expression. ${ }^{x}$ Suffragists created their own classics and their own authority. This first part will focus on three different aspects of suffragists' texts as ways to articulate literature and politics to express women's power: they provided a space or a framework for participation in political debates thanks to the dialogic form; they were pedagogical tools to educate the reader; they used humor as a political weapon to subvert authority and demonstrate that woman suffrage was necessary.

7 Suffrage publications aimed first at appropriating political language to show that women were able to participate in political debates. They provided a space for political dialogues in absentia and created a voice that allowed forms of "textual ventriloquism" (Chapman 5). They were 
forms of representation and dramatization of real situations, or provided an idealized context in which suffragists could safely express their points of view in less threatening or inappropriate ways than in the controversial publicity of streets or meeting halls. They could then be perceived by suffragists as more effective ways to convert an audience to the cause. According to Chapman, suffragists could "appropriate the dominant (male) body and usurp its voice," thus speak more freely as their gendered bodies remained invisible (Chapman 5). Indeed, for suffragists, using literature allowed detachment thanks to the ambiguous status of authorship, different from that of speaker or essayist, as the author was not necessarily identified with the content of the work (Chapman 5).

8 Nicknamed the "poet laureate of the cause," poet and novelist Alice Duer Miller published numerous poems to publicize the movement. ${ }^{\mathrm{x} i}$ Her verses were described by The New York Times as "sarcastic, humorous" ("Woman Suffrage Campaign in Books"), which might have been a way for the anti-suffrage newspaper to depoliticize the poems by relegating them to forms of witty conversations. Are Women People? is a collection of poems originally published in the pro-suffrage New York Tribune that were in fact answers to anti-suffrage speeches or publications. Miller's rhymes riposted to declarations by Democratic US Representative Edwin Yates Webb, chair of the Judiciary Committee ("Our Idea of Nothing at All"), Stanley E. Bowdle, Democratic US Representative from Ohio ("Lines to Mr. Bowdle of Ohio"), Charles David Carter, Democratic US Representative from Oklahoma ("On Not Believing All You Hear"), Vice-President Marshall, President Wilson, and other masculine figures of authority. Each of the poems provides a quotation from one of these men as frontispiece or epigraph and develops a retort to the quotation. For example, the poem entitled "Lines to Mr. Bowdle of Ohio" gives a passage taken from Bowdle's antisuffrage speech in Congress as follows: "'The women of this smart capital are beautiful. Their beauty is disturbing to business; their feet are beautiful, their ankles are beautiful, but here I must pause.'-Mr. Bowdle's anti-suffrage speech in Congress, January 12, 1915)" (Miller 14)
9 Then the poem begins:
YOU, who despise the so-called fairer sex,
Be brave. There really isn't any reason
You should not, if you wish, oppose and vex
And scold us in, and even out of season;
But don't regard it as your bounden duty
To open with a tribute to our beauty. (Miller 14)

10 The opening of the poem, with the accusatory "YOU" in capital letters, is a shout at the Democratic Representative on the page. The poem is a reminder of how men talk about women and for women, at the same time developing the poet's own voice. This discursive method is reminiscent of suffragists' militant tactics of heckling in the 1910s. They went to politicians' meetings and interrupted speeches by asking loudly 
about women's rights, making literally their voice heard in a male dominated room. ${ }^{x i}$ Furthermore, while lobbying for their political rights, suffragists always wrote down the verbatim declarations of politicians, and used them to point to their inconsistency (Park 38-40). Deconstructing hypocritical or conflicting behavior and discourse was an important strategy of the suffragists. Using quotations taken from anti-suffragists' discourse as textual frames, Miller's poems provide argumentative answers to anti-suffragists' opinions. Some of Alice Duer Miller's poems also responded to editorials published in The New York Times: "Oh, That "Twere Possible!" (Miller 39) and "The Times Editorials" (Miller 40). This type of semi-dialogic debate between suffragists and anti-suffragists was common in newspapers thanks to the publications of letters to the editor. Suffragists' and anti-suffragists' organizations sent pieces to newspapers and poetry was used by advocates of both the causes to promote their views. Yet, as was the case with heckling, the exchange could be considered as limited to outbursts of discourse, out of context, with no real response following up, because most of the time, politicians did not respond to suffragists' interruptions. As voices of dissent, they were probably ignored because they did not abide by the rules of male political debates and because they were the powerless voices of the disenfranchised. Newspapers created a complicated network of pro- and anti-suffrage texts that were not directly answering each other but were more like bits and pieces of a never-ending argument, even though the publications allowed for the development of lengthier argumentation.

11 Apart from providing a space for imaginary debate through dialogue, poems, short stories, novels, and plays were also ways to educate the audience about the necessity of woman suffrage through pedagogy and denunciation. xiii Depicting women's "real" situations without the vote in novels or unfolding arguments through dialogues on stage were believed to have a persuasive power. Suffrage plays were performed in schools, and A Modern Madonna (1906) by Caroline Abbot Stanley, described as the "American Suffrage Novel," was read at Cumnock School in Los Angeles in 1910 ("To Speak Pieces to Music of Psaltery"). xiv The first chapters of Marietta Holley's Samantha on the Woman Question (1913) present a series of women's arguments for the vote by giving examples of women's dire situations without it. ${ }^{\mathrm{xv}}$ Samantha was a popular character and the heroine of a series of novels. She represents a somewhat naïve rural woman, but who is also rational and logical and displays common sense. She embodies the perfect character to educate the reader and can be considered a humorous avatar of Bildungsroman characters. Most of the "Samantha novels" follow the same narrative pattern. The story opens with an event that will send Samantha on a journey, her travels mirroring her discoveries and her acquisition of knowledge. The move from the country to a city points to the social, economic, and political transformations of the United States at the time, with the transition and adaptation from a rural, preindustrial society to a capitalist, urban environment. In the 
second chapter of Samantha on the Woman Question, Samantha's female neighbor Serepta Pester, upon learning that Samantha is about to set off to go to Washington, asks Samantha to lobby for her. Samantha first thinks it is "some new kind of tattin' or fancy work" or "a new kind of dance," and when Serepta asks her to canvas some of the Senators, Samantha thinks that she is asking her to buy a piece of cloth (Holley 15). Serepta explains her reasons for wanting Samantha to lobby politicians. She laments "wimmen's helpless condition under the law" and tells about how "the Whiskey Ring" has destroyed her rights (Holley 16). Serepta's sister Azuba is in the poorhouse because her husband's drinking has ruined them. Her cousin is in the "lunatick asylum" as she was "at the mercy of a brute in a man's shape." Her Aunt Cassandra is in jail as she refused to pay extravagant taxes (Holley 17-20). Such examples personalized political conflict thanks to the stories of various characters. The different conditions of women in Serepta's circle embody suffrage argumentations: women were the victims of men's violence and drinking habits and the right to vote would cure these ills. Such stories epitomized some women's experiences at the time, but they transposed suffragists' argumentations in fiction and thanks to the personification of these arguments through characters, the ideas were in turn fleshed out.

${ }_{12}$ As was illustrated by the character of Samantha, suffragists used humor in their writings. It served two purposes: on the one hand, it represented a form of dissent and transgression, and, on the other, it might have been thought of as a means to convince the reader, as pointed out by George Middleton ${ }^{\text {xvi }}$ who wrote Back of the Ballot (1915), a farce in one act. In the introduction to the play, Middleton asserts that he wrote "frankly for propaganda and fun" (Middleton 3). He also adds: "I have had in mind the phrase that 'when argument fails, try laughter,' and so I dedicate this to my friends among the 'Antis'" (3). In her novels, Marietta Holley also used satire to denounce social ills. As remarked by Winter, men "who would not listen to a feminist speaker's arguments would read Holley's books with delight, accepting through her humor the subversive notions of suffragist thought" (Winter 7). Humor may also have been a form of outlet to express or channel suffragists' frustrations. Indeed, as suffragists mocked male discourses, they deconstructed their power. In her poems, Alice Duer Miller embraced humor as a subversive tool to undermine the authority of male judges or politicians. Her work participated in a culture of public amusement through its depiction of ridiculous political candidates. She clearly mocked their arguments. In "On Not Believing All You Hear," she quoted the anti-suffrage speech of Representative Charles David Carter, "Women are angels, they are jewels, they are queens and princesses of our hearts," and answered with the following:

Angel, or jewel, or princess, or queen,

Tell me immediately, where have you been?

I've been to ask all my slaves so devoted

Why they against my enfranchisement voted. 
Angel and princess, that action was wrong.

Back to the kitchen, where angels belong. (Miller 46)

In this poem, Miller thus mocks the representation of women and contrasts Carter's flowery language with a more prosaic image in the last line with the injunction "Back to the kitchen."

${ }_{14}$ Suffragists' literary productions functioned as compensatory modes of political expression to assert women's power. They developed women's voices, viewpoints and arguments, and challenged figures of authority. They thus belonged to a larger popular culture of humor and political satire.

\section{Playing with Words: Adapting and Rewriting the Literary Canons}

${ }_{15}$ Suffragists' works were adapted to popular literary tastes of their times-sentimental novels in the 1870s, realist texts at the end of the nineteenth century-whereas writers in the 1910s wrote "middlebrow narratives," whose themes depicted the problems of their time, which echoed Progressives' concerns and even xenophobia (Petty 8). Suffragists' publications were also used for fundraising and they catered to the taste of the American audience at the time; in this respect, these texts were part of popular literature and of the publishing economy. In the last years of the struggle, the suffrage campaign "coincided with an adjacent campaign among aesthetic modernists to renovate literary style through formal experiments in voice, perspective, and intertextuality" (Chapman 12). Suffrage literary writings thus relied on experimentation in terms of form and style, which could be considered as a reevaluation of power relations. For instance, in her chapter devoted to Elizabeth Robins's theater, Sheila Stowell highlights how suffragists" plays were "a conscious attempt to construct an 'authentic' woman's drama" in response to "maledetermined or male-imitative playmaking" (2). Robins's play Votes for Women! questioned aesthetic postures as much as gender expectations. It is therefore worth examining how suffrage writings could question issues of power through new forms of expression, mainly through fragmentation and rewriting. Literary productions as transfigurations and representations of reality turned politics into forms of creativity. The suffragists' texts were not just pamphlets in disguise, since they could also question and play with form. What was the political meaning of these experimentations?

16 The Sturdy Oak puts stress on the dissolution of authorial power through its experimental form as a collective novel. In 1916, twentyfive female and male authors announced that they would collaborate on a novel dedicated to Anna Howard Shaw, the former vice-president and president of the National American Woman Suffrage Association ("25 to Collaborate on Suffrage Novel”). Each writer was supposed to freely develop his or her chapter. The project included prominent authors at 
the time, such as Samuel Merwin, Kathleen Norris, Harry Leon Wilson, Elizabeth Jordan and Dorothy Canfield.xvii The project reached completion in 1917 under the title The Sturdy Oak, which was the work of fourteen different authors and was serialized in Collier's Weekly. The scheme, based on a parlor game where one person begins a narrative that another continues, was creatively innovative and echoed modernist perspectives in its composite dimension. This experiment was a political stance by presenting a new distribution of power thanks to multivocality. As such, it can be seen as a reflection on a possible revitalizing of US democracy and as a metaphor for an American public sphere in which different groups would be given a voice.

${ }_{17}$ Playing with forms as much as themes, suffragists used literary classics, rewriting and reworking them. The tampering with classical texts and the search for a new form could be seen as epitomizing deconstruction of traditions while asserting new voices and new viewpoints, once again exploring new possibilities of power. Mary Chapman cites the parody of William Blake's "Tyger, Tyger, Burning bright," entitled "Anti, Anti, Burning Bright" (Chapman 96). Miller's collection of poems Are Women People? is reminiscent of palimpsests because it includes famous poems that have been rewritten: "O that 'twere possible" by Lord Tennyson ("Oh, That "Twere Possible!"), James Whitcomb Riley's "A Life Lesson" ("The Protected Sex"), in which she replaced the first verse "There! Little girl, don't cry!" by "There, little girl, don't read!" (Miller 39, 34-35). She also rewrote Robert Louis Stevenson's "Whole Duty of Children":

A child should always say what's true

And speak when he is spoken to,

And behave mannerly at table;

At least as far as he is able.

The original poem thus became:

A heroine must be polite

And do what others say is right,

And think men wise and formidable 閶

At least as far as she is able. (Miller 61)

Miller also revisited "Candor" by Henry Cuyler Bunner (Miller 69), while "The Ballad of Lost Causes" refers to French poet François Villon's "Ballad of the Ladies of Bygone Times" with its first verse, "Tell me in what spot remote" (Miller 84). Miller plays with references and language, mixing both lofty and prosaic registers. Her poetry deals with the mundane and includes bits of everyday conversations. As such, it could be argued that Miller's quest for emancipation was also about poetic forms. Her poems, including quotations from different sources, could be seen as modern types of collage, a hodgepodge of multiple voices. Alice Duer Miller's experimentation with forms was used to debunk anti-suffragists' arguments, as epitomized in her series of poems "Why We Oppose Pockets for Women" and "Why We Oppose Women Travelling in Railway Trains." In these poems, she wrote lists that stress the absurdity of anti-suffragists' statements, as illustrated by 
the following excerpt: "1. Because pockets are not a natural right. / 2 . Because the great majority of women do not want pockets. If they did they would have them. / 3. Because whenever women have had pockets they have not used them." Not only is the gist of anti-suffragists' arguments here deconstructed thanks to the transposition of the suffrage debate into a mundane issue, that of whether women should have pockets, but the specific form of the list points to an accumulation of absurd statements taken out of their original context. The list could also refer to a shopping list, thereby highlighting not only the inscription of the suffrage movement into a growing consumer environment, but also suggest that anti-suffragists "shop" for arguments that are disconnected from one another, do not form a coherent whole, and can quickly be substituted by any other.

20Suffragists' experiments in forms were part of a larger movement to explore new literary possibilities. They can however be considered as a definite political stance by deconstructing the authoritative figure of the author, tampering with existing texts or crafting hodge-podge of different voices or ideas. The search for new forms tied in with the political challenge that the woman suffrage campaign embodied. As such, these experiments could be studied along with other texts, such as essays, pamphlets or discourses, as they testify to the understanding of suffrage rhetoric and oratory, which were key components of suffragists' political struggle. Furthermore, this subversive deconstruction of figures of power could attest to the cultural belief in the power of language as a possible tool for women to assert their emancipation. Reading and writing were thus key elements of the woman suffrage political campaign and experience.

\section{Changing the World: Suffrage Literary Writings and Historical Conditions}

21From the very beginning of the women's rights movement, fiction was portrayed as providing powerful tools to change the world. In the first issue of The Una: A Paper Devoted to the Elevation of Woman, the first major woman's rights paper launched in February 1853, xviii the article entitled "The Truth of Fiction, and Its Charms" advocated the use of fiction to promote the cause:

Making no pretensions on and limited by none of the laws of narrative, truth and historical fact, [fiction] brings the truth of nature-the probable, the possible and the ideal-in their broadest range and utmost capabilities into the service of a favorite principle, and demonstrates its force and beauty, and practicability, in circumstantial details, which like a panorama, presents an image so like an experience that we realize it for all the purposes of knowledge, hope and resolution. (quoted in Petty 4)

22 According to this article, fiction retained both an ontological and a political dimension. It expresses "the truth of nature" while suggesting the possibility of an alternative society. As such, literature is a "prime 
medium for challenging and rewriting gender norms" (Petty 4). Let us therefore examine the way fiction was portrayed by suffragists as a way to possibly change historical conditions and how the influence of the suffrage movement on literature was discussed by newspapers at the time.

23Some texts provided experimental visions of society, as was the case with the novel Angel-Island, which embodies an attempt by Inez Haynes Irwin, a member of the suffragist organization the National Woman's Party, at writing a novel in service of the cause. Inez Haynes Irwin gave an interview for The Hartford Herald in September 1913, in which she discussed the issue of form ("Noted American Story-Writer"). She recounted that she had been for many years looking for "the best

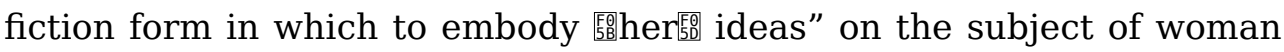
suffrage. She explained that she had planned and given up many suffrage novels. But her new novel, Angel-Island, which put men and women on an inhabited island and let them work out the political issue "in primitive conditions," was told in "the fable-form," which was for her "the most telling way of convincing the unconvinced." Inez Haynes Irwin named as her sources of inspiration Aesop, Maeterlinck, Rostand, and Swift's Gulliver's Travels, which "taught some of us more about the human kind than all the histories, homilies and essays ever written" ("Noted American Story-Writer"). The novel is described as a fantasy or science fiction, ${ }^{\text {ix }}$ but it could also be described as a sort of utopia / dystopia. Indeed, a group of men is shipwrecked on a desert island, where they soon spot beautiful flying creatures that turn out to be winged women. The men then capture the women and cut their wings off. The brutality of the men and their violent effort to discipline women into a patriarchal domestic system and the helplessness of the women who cannot walk or fly without their wings are metaphors of women's powerlessness without the vote. Other works, such as $A$ Woman for Mayor: A Novel of Today, written by Helen L. Winslow ${ }^{\mathrm{xx}}$ and published in 1909, anticipated the moment when women would vote, and presented different relations between men and women as well as women's potential new roles. A review in The Salt Lake Tribune of $A$ Woman for Mayor depicted these views as nonsensical:

It goes on the assumption that when woman votes women will be elected to important offices, a fallacy disproved wholly in the four 'suffrage' States of Colorado, Idaho, Utah, and Wyoming, where women in office are about as scarce as women jurors, and where women are expressly excused by law from jury service. ("A 'Suffrage' Story")

24Suffragists used literature as a political tool in all their campaigns in the public sphere. For example, in November 1912, suffragists organized a huge evening parade in New York City during which they tossed "candy and arguments into the crowd." On one of the floats, “beauteous maidens 嚂were監 flinging candies to the crowd-a suffrage

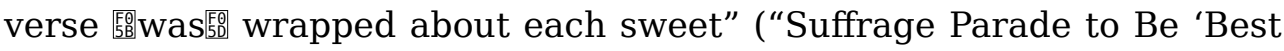
Ever'”). In the summer of 1911, the New York City Woman Suffrage 
Party organized a national poetry contest to find a "majestic and impassioned national suffrage hymn" and to galvanize support. A prize of a hundred dollars was promised to the author of a song that would "take hold of the whole being and make itself sung by the masses" ("A Suffrage Hymn Contest"). Memorable songs were sung during parades. In their campaign for the vote in the 1910s, as suffragists increasingly took to the streets to promote their cause through pageants, parades, tableaux, and plays, they blurred the lines between the streets and the stage. Any public space could be turned into an impromptu theater, as had been symbolized by soapbox speakers. Suffragists made spectacle and performance part and parcel of their political endeavor, turning the cause into a drama. Plays played of course a central role, as highlighted by a July 1915 article in The Washington Times: "The play, 'War Brides,' will be one of the principal campaign documents of the Congressional Union for woman suffrage this summer" ("War Brides' to Be Used in Suffragists' Campaign"). As "campaign documents," plays were used to promote the cause directly to the public during open air meetings. They were also performed in private homes, but people bought tickets to attend, and they were read in public. They dramatized suffragists' arguments, but they were also valued as entertainment. They served as amusements between lectures ("Lectures and Plays For Woman Suffrage") and their success did captivate theater producers. ${ }^{\text {xxi }}$ Suffrage plays were so popular that anti-suffragists published lists of these works and called for a boycott of the theaters where they were performed ("War is Declared on Pro-suffrage Plays").

${ }_{25}$ Plays were part of suffragists' media strategy and preparations, and rehearsals were covered by newspapers. ${ }^{x x i}$ Successful plays were also turned into movies, such as "Your Girl and Mine." The author of the article reviewing the movie for The Washington Times stresses that "the

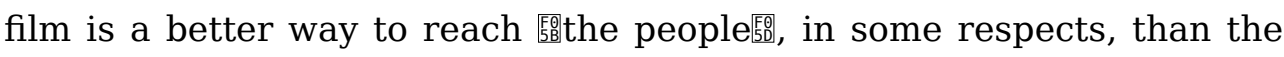
book, or the pamphlet, or the newspaper." The film included "big stage stars" (actress Olive Wyndham was the leading role) alongside Anna Howard Shaw "shown in the picture addressing a meeting of women." Furthermore, the film was expected to help out the treasury of the National American Woman Suffrage Association thanks to "a big royalty from the film" ("Real Thrills in the Woman's Suffrage Propaganda Film Play").

26Suffrage novelists offered a societal mirror, a reflection and interpretation of their environment, to readers. They helped them make sense of the changing world around them. Proponents of the cause wrote novels in which the New Woman played a prominent role, mirroring women's evolving roles. Newspapers often commented on the social value of these works. Gertrude Atherton'sxiiiJulia France and Her Times, though set for the most part in England, was described in The New York Times as a "period novel,"even if the "period of history the period of to-day," and it "record嚂ed區 the woman's war" ("For Woman Suffrage"). Atherton was considered by the reviewer as not 
indulging in "blatant propaganda at the expense of interest or of art," and her novel was praised for its accurate account of modern life. In July 1915, The New York Times Review of Books noticed:

A very interesting feature of the development of feministic literature during the last three or four years is the marked influence it is having upon works of the imagination. The novel has been profoundly affected. Its themes, its characters, its problems all show the influence of the feministic agitation. ("Woman Suffrage Campaign in Books")

27Margaret Deland's novel The Rising Tide (1916), whose title implied that woman suffrage was imminent, was reviewed by The New York Times which underlined the omnipresence of the issue. ${ }^{\text {xiv }}$ The fact that woman suffrage was part of the American daily environment was also stressed with the reference to suffrage parades: "The scene of the story is in a city somewhere in the eastern part of the Ohio Valley, a city with wealth and poverty and social castes, workingwomen's problems, suffrage parades, and old-fashioned ideas" ("Mrs. Deland's Feminist Heroine"). Another example was The Cost of a Promise, which offered, according to The New York Times, "塸臨 very old-fashioned plot with upto-date variations," as the heroine "goes into an office instead of becoming a down-trodden governess, joins the Woman Suffrage Society and provides the most interesting chapter in the book by attending a political meeting and questioning the candidate as to his position on 'Votes for Women'" ("Cost of a Promise"). The rendering of suffrage meetings was a climactic scene in literary works steeped in realism. The second act of Votes for Women! recreates a suffrage rally with the speakers and the heckling crowd (Nelson 181).

28The newspapers recognized the "woman suffrage novel" as a specific genre, as noticed by The Salt Lake Tribune in 1909: "This is distinctly and avowedly a 'suffrage novel'" ("A 'Suffrage' Story"). The literary and political genre was publicly discussed in newspapers and lecture halls. In The New York Times Review of Books of July 1915, a list of suffrage fiction was recommended for reading. ${ }^{\mathrm{xx}}$ These works were praised for their contemporary accuracy and for showing the evolution of women's social conditions.

29Literary productions were central to suffragists' political struggle. They allowed social criticisms and the postulation of a different world, they helped to promote political arguments at home and in the public sphere, and their influence was recognized by newspapers. The embedding of the woman suffrage movement in works also mirrored a social reality of the time and the influence of suffrage on popular culture. Maybe it highlights that suffrage became a selling argument for literary production, a way to please the public, or a cliché to capitalize on. The discussion on the importance of the representation of suffrage struggle in literature may be seen as a reflection of the power of the movement on the streets.

30Suffrage literary works seem to have been partly neglected, even though the bulk of writings dedicated to the cause was very important. 
One of the reasons for this disregard is clearly connected to the very nature of suffrage publications as political texts. Once the $19^{\text {th }}$ amendment was passed in 1920, there was no interest in texts whose polemical dimension had disappeared. But as stressed by Chapman and Mills, there is a need for a recovery of suffrage texts that have long been out of print (Chapman and Mills 4), a task the two critics undertook in 2011. xxvi Recovering these documents will be of value to the historian on many levels. First, taking into account suffrage literature as a significant source vitalizes historical practice: it highlights how cultural productions were embedded in reform movements, how literary writings were, on many levels, part of the advancement of American democracy, showing the articulation between popular culture and politics. Literary works participated in the dissemination of suffragists' ideas and emphasized how creative the movement was. They ought to be acknowledged as central in suffragists' endeavor to promote their cause in the public sphere. In this respect, they highlight how suffragists used entertainment to promote their cause. In this respect, suffragists participated in the denunciation of the behavior of political candidates for public amusement. Fiction can also highlight another relation between language and ideology, and provide other discursive sources to study suffrage rhetoric. As "tracts in fiction," they can add to the bulk of sources (speeches, pamphlets, essays) used to analyze suffragists' art of persuasion. Furthermore, these texts can help turn historical conditions into something more intelligible. Finally, the production and reproduction of these texts were affected by the economic, political, social and intellectual conditions of the time, and they are an historical challenge. There is a need for further exploration of suffrage authors, their publishers, the ways the books were publicized and discussed. Miller, Holley, Jordan and Irwin seem to have been quite wellprospering authors. What was the role played by suffrage literature in the larger context of print culture at the turn of the twentieth century? In 1914, The New York Tribune asserted that "no best seller [was] complete nowadays without a few suffragettes mixing in the plot-see any publisher's latest list" ("Literary Lights Are Lined Up For Votes"). Were the relations between authors relevant to the suffrage movement? The links and connections between authors could point to the development of a network of suffrage authors. Reading was an important social activity and it would be also interesting to look into the textual construction of an audience but also the practice of reception aesthetics. In this respect, the role of booksellers and librarians ought to be explored. In 1916, the first bookshop "planned and stocked exclusively for women opened" (Tebbel 176). Moreover, the material conditions affecting the availability of suffrage literature is an important issue, very relevant for the perception of the suffrage movement. The source texts can be used in political history, social history, and book history. Thus, suffrage literary writings were and still are political acts, cultural texts and historical sources. 


\section{BIBLIOGRAPHY}

“25 to Collaborate on Suffrage Novel.” New York Tribune, April 29, 1916.

“Act Mrs. Burleson's Play.” The New York Times, December 16, 1913.

Amlon, Terri A. Women of Reform: The Periodical Editing Careers of Margaret Fuller, Lydia Maria Child, Caroline Healey Dall, and Jane Grey Swisshelm, Diss., University of South Carolina, 2006. Print.

Bardes, Barbara and Suzanne Gossett. Declarations of Independence: Women and Political Power in Nineteenth-Century American Fiction. New Brunswick, N.J.: Rutgers UP, 1990. Print.

Blair, Karen J. “Pageantry for Women's Rights: The Career of Hazel MacKaye, 1913-1923." Theatre Survey: The Journal of the American Society for Theatre Research 31.1 (May 1990): 23-46. Print.

Cane, Aleta Feinsod, and Susan Alves, eds. "The Only Efficient Instrument": American Women Writers and the Periodicals 1837-1916. Iowa City: U of Iowa P, 2001. Print.

Chapman, Mary. Making Noise, Making News: Suffrage Print Culture and U.S. Modernism. New York: Oxford UP, 2014. Print.

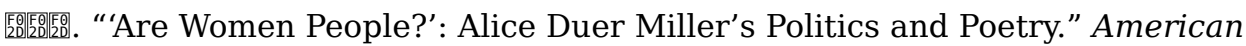
Literary History 18.1 (Spring 2006): 59-85. Print.

Chapman, Mary, and Angela Mills, eds. Treacherous Texts: U.S. Suffrage Literature, 1846-1946. New Brunswick, N. J.: Rutgers UP, 2011. Print.

Clark, Anne B. My Dear Mrs. Ames: A Study of Cartoonist Blanche Ames. New York: Peter Lang, 2001. Print.

“Cost of a Promise." The New York Times, October 18, 1914.

Corkrey, Lara Hernandez. Marietta Holley, Alice Duer Miller, the Rhetoric of Suffrage Humor, and the Changing Notions of Womanhood, 1848-1920. Diss. University of Kansas, 2007.

Crew, Danny O. Suffragist Sheet Music: An Illustrated Catalogue of Published Music Associated with the Women's Rights and Suffrage Movement in America, 1795-1921, with Complete Lyrics. Jefferson, N.C.: McFarland, 2002. Print.

Darnton, Robert. "What Is the History of Book?" The Case for Books: Past, Present, and Future. New York: Public Affairs, 2009. Print.

Eysteinsson, Astradur. The Concept of Modernism. Ithaca and London: Cornell UP, 1990. Print.

Honey Maureen. Introduction. Breaking the Ties that Bind: Popular Stories of the New Woman, 1915-1930. Ed. Maureen Honey. Normann: U Oklahoma P, 1992. 3-36. Print.

Felski, Rita. Beyond Feminist Aesthetics: Feminist Literature and Social Change. Cambridge, Mass.: Harvard UP, 1989. Print. 
Finnegan, Margaret. Selling Suffrage: Consumer Culture \& Votes for Women. New York: Columbia UP, 1999. Print.

“For Woman Suffrage: Mrs. Atherton's New Novel a Sketch of the Modernized Woman," The New York Times, April 21, 1912.

Friedl, Bettina, ed. On to Victory: Propaganda Plays of the Woman Suffrage Movement. Boston: Northeastern UP, 1987. Print.

Gilman, Charlotte Perkins. Suffrage Songs and Verses. 1911. Gloucester: Dodo Press, 2008. Print.

Harker, Jaime. America the Middlebrow: Women's Novels, Progressivism, and Middlebrow Authorship Between the Wars. Amherst: U of Massachusetts P, 2007. Print.

Hogeland, Lisa Maria. Feminism and its Fictions: The Consciousness-Raising Novel and the Women's Liberation Movement. Philadelphia: $\mathrm{U}$ of Pennsylvania P, 1998. Print.

Holley, Marietta. Samantha on the Woman Question. New York: Fleming H. Revell Company, 1913. Archive.org. Web. 9 Dec. 2015.

Howard, June. Publishing the Family. Durham and London: Duke UP, 2001. Print.

John, Angela V. Elizabeth Robins: Staging a Life, 1862-1952. New York: Routledge, 1995. Print.

Jordan, Elizabeth, ed. The Sturdy Oak. New York: Henry Holt and Company, 1917. Archive.org. Web. 9 Dec. 2015

"Lectures and Plays for Woman Suffrage." The Washington Times, February 15, 1912.

"Literary Lights Are Lined Up For Votes." The New York Tribune, January 11, 1914.

Lumsden, Linda. Rampant Women: Suffragists and the Right of Assembly. Knoxville: The U of Tennessee P, 1997. Print.

Middleton, George. Back of the Ballot: A Woman Suffrage Farce in One Act. New York: Samuel French, 1915.

Miller, Alice Duer. Are Women People? A Book of Rhymes for Suffrage Times. New York: George H. Doran Company, c1915. National American Woman Suffrage Association Collection, Library of Congress. Web. 9 Dec. 2015

http://hdl.loc.gov/loc.rbc/rbnawsa.n3348

“Mrs. Deland's Feminist Heroine." The New York Times, August 20, 1916.

Nelson, Carolyn Christensen. Literature of the Women's Suffrage Campaign in England. Orchard Park, NY: Broadview Press, 2004.

“Noted American Story-Writer.” The Hartford Herald, September 3, 1913.

"Noted Novelist's Plea for Women: Stirring Appeal for the Suffrage in Elizabeth Robin's Book, 'The Convert'-A Tract in Fiction." The New York Times, November 16, 1907. 
Park, Maud Wood. Front Door Lobby. Dir. Edna Lamprey Stantial. Boston: Beacon Press, 1960. Print.

Petty, Leslie. Romancing the Vote: Feminist Activism in American Fiction, 1870-1920. Athens and London: The U of Georgia P, 2006. Print.

"Real Thrills in the Woman's Suffrage Propaganda Film Play." The Washington Times, January 12, 1915.

Reginald, Robert ed. Science Fiction and Fantasy Literature: A Checklist, 1700-1974, vol. 1, Detroit: Gale Research Company / Book Tower, 1979. Print.

Rehm, Maggie Amelia. The Art of Citizenship: Suffrage Literature as Social Pedagogy. Diss. University of Pittsburgh, 2011. Print.

Ross, Stephen. "Introduction: The Missing Link." Modernism and Theory: A Critical Debate. New York: Routledge, 2009. Print.

Salmonson,Jessica A. What Did Miss Darrington See?: An Anthology of Feminist Supernatural Fiction. New York: The Feminist Press at The City University of New York, 1989. Print.

Sheppard, Alice. Cartooning for Suffrage. Albuquerque: U of New Mexico P, 1994. Print.

Solomon, Martha ed. A Voice of Their Own: Woman Suffrage Press 1840-1910. Tuscaloosa: U of Alabama P, 1991. Print.

Stowell, Sheila. A Stage of Their Own: Feminist Playwrights of the Suffrage Era. Manchester: Manchester UP, 1992. Print.

"A Suffrage Hymn Contest." Chariton Courier, September 1, 1916.

"Suffrage Parade to Be 'Best Ever'." New York Tribune, November 9, 1912.

“A 'Suffrage' Story.” The Salt Lake Tribune, June 27, 1909.

“To Speak Pieces to Music of Psaltery." Los Angeles Herald, July 21, 1920.

Tebbel, John. A History of Book Publishing in the United States. Vol. 2. New York, London: R. R. Bowker, 1975. Print.

"War Brides" to Be Used in Suffragists' Campaign." The Washington Times, July 9, 1915.

"War is Declared on Prosuffrage Plays." The Washington Herald, February 11, 1914.

Welter, Barbara. "The Cult of True Womanhood: 1820-1860," American Quarterly 18.2 (1966): 151-174. Print.

Winter, Kate H. Marietta Holley: Life with Josiah Allen's Wife. Syracuse, NY: Syracuse UP, 1984. Print.

"Woman Suffrage Campaign in Books." The New York Times Review of Books, July 11, 1915. 


\section{NOTES}

i. Elizabeth Robins (1862-1952) was an American novelist, a playwright, an actress and a suffragist, who moved to London in 1888. She wrote Votes for Women!, a suffrage play produced at the Royal Court Theatre in London in 1907. See Angela V. John.

ii. The New York Times published both pro-suffrage and anti-suffrage articles. However, the editorial published on November 11, 1917, "Seeking Federal Suffrage," was clearly opposed to woman suffrage.

iii. Laura Curtis Bullard (1831-1912) was a writer and a women's rights activist. She was elected corresponding secretary for the National Woman Suffrage Association upon its founding in 1869. She wrote articles for The Revolution and became its editor in 1870. She was a member of the literary society Sorosis. Her two novels Now-a-days! (1854) and Christine: or, Woman's Trials and Triumphs (1856) pleaded for women's rights.

iv. As noted by Stephen Ross, the concept of modernism has been renewed in recent years: "[a]ny consensus about modernism in the singular has given way to numerous and disparate understandings of modernisms in the plural, as the old geographical, temporal, and material limits on what qualified as modernism have been determinedly dismantled." As a consequence, modernism has been "recast by the new modernist studies as a cultural formation occurring in different forms, in different times, and in different places (...) that recognizes its own historicity and challenges prevailing pieties." (Ross 1)

v. The inclusion of suffragists' literary productions might illuminate studies about suffragists' print culture, a topic that has been mostly analyzed through the suffragists' dynamic press, and studies about suffragists' use of art to promote their cause, a question that has been tackled through suffragists' pageants and other spectacles on the streets. On suffrage periodical culture, see Cane and Alves; Finnegan; and Solomon. On cartoons, see Anne B. Clark; and also Sheppard. On pageantry, see Blair; see also Lumsden 96-113.

vi. Alice Duer Miller was Chair of the Committee on resolutions of the National American Woman Suffrage Association and wrote a popular weekly column for The New York Tribune, whose circulation on Sundays exceeded 100,000. See Mary Chapman, who explains how popular Miller was throughout her career (“'Are Women People?'," 67-68). Marietta Holley was described as the "Female Mark Twain," and was a very popular author (Winter 1). She had strong ties to the woman's movement and was invited to speak to the US Congress on women's rights, which she declined (Winter 6-7). Elizabeth Jordan, who edited The Sturdy Oak, a collaborative novel written to raise money for the suffrage cause, was the ghostwriter for suffragist leader Anna Howard Shaw's autobiography The Story of a Pioneer (Howard 189). Anna Howard Shaw was a very important figure of the suffrage movement, which she joined in the late 1880s. She became president of the National Woman Suffrage Association in 1904 for 11 years, before resigning in 1915. Inez Irwin co-founded the College Equal Suffrage League with Maud Wood Park in 1900 and was a member of the National Woman's Party.

vii. Book historians focus on "how ideas were transmitted through print and how exposure to the printed word affected the thought and behavior of mankind" (Darnton 176). Darnton underlines that despite "a considerable 
literature on its psychology, phenomenology, textology, and sociology, reading remains mysterious" (201).

viii. Tebbel speaks of a wave of feminist novel writing in 1895 and observes a steady growth in book productions. For instance, in 1907 the total book production was 9,620 and in 1913, the number was 12,230.

ix. True Womanhood and the Cult of Domesticity were discussed by Barbara Welter.

x. Suffragists also used texts written by men to promote the cause. Aristophanes' Lysistrata was for example performed in New York, "Sit in a Drizzle to See Greek Play," New York Times, September 20, 1912.

xi. Alice Duer Miller (1874-1942) was a poet, a novelist, and a screenwriter. Her writings include the Blue Arch (1910), Come Out of the Kitchen (1916), Are Parents People? (1925), The White Cliffs (1940).

xii. On July 2, 1914, The New York Times published an article "Heckling the President," that rebuked women for "catechizing" Woodrow Wilson and crossexamining him. When Wilson laid the cornerstone of the Labor Temple of the American Federation of Labor, Mabel Vernon interrupted him. See "Wilson Advises Calm Counsel," New YorkTimes, July 5, 1916.

xiii. The different literary genres provided different means to express suffrage ideas in different forms and styles, from dialogic debates to narrative patterns of conversion.

xiv. "How the Vote Was Won" was performed by dramatic associations in a D.C. school. See for example "In the Schools," Evening Star, November 9, 1913. Caroline Abbot Stanley (1849-1919) was a schoolteacher and principal in Kalamazoo, Michigan. Her works include Order No. 11, A Modern Madonna, The Master of the Oaks and The Keeper of the Vineyard.

xv. Marietta Holley (1836-1926) was a very successful humorous writer, whom critics often compared to Mark Twain. The Samantha series includes Samantha among the Brethren, Samantha on the Race Problem, and Samantha at the St. Louis Exposition.

xvi. George Middleton (1880-1967) was a proponent of one-act plays. His theatrical successes include Polly with a Past (1917) Adam and Eva (1919).

xvii. Samuel Merwin (1874-1936) wrote Anthony the Absolute (1914) and The Honey Bee: A Story of a Woman in Revolt (1915). Kathleen Thompson Norris (1880-1966) wrote novels, short stories and newspapers' columns. She published her works in The Atlantic, The Saturday Evening Post, Ladies Home Journal and other magazines. Her popular novels include Mother (1911), Saturday's Child (1914), and Martie The Unconquered (1917). Harry Leon Wilson (1867-1939) was a dramatist and a novelist. His works include Bunker Bean (1912) Ruggles of Red Gar (1915) and Merton of the Movies (1922). Elizabeth Jordan (1865-1947) started her career at the St Paul Globe and Chicago Tribune before working for the New York World. She was editor of Harper's Bazaar from 1900 to 1913. A staunch suffragist, she collaborated with Anna Howard Shaw on Shaw's biography, The Story of a Pioneer (1915). She published numerous works, including Many Kingdoms (1908), Wings of Youth (1917), The Girl in the Mirror (1919). Dorothy Canfield Fischer (1879-1958) was engaged in many reform movements, including prison reform and education (she introduced the Montessori method to the United States). She published The Squirrel-Cage (1912), The Real Motive (1916), Understood Betsy (1917), The Home-Maker (1924). 
xviii. The Una: A Paper Devoted to the Elevation of Woman was co-edited by Caroline Healey Dall and Paulina Wright Davis. It was to "discuss the rights, sphere, duty and destiny of woman, fully and fearlessly." It was published monthly and started in February 1853 in Providence, Rhode Island. See Amlon 115.

xix. Jessica Amanda Salmonson calls Angel Island "a Swiftian fantasy with radical feminist twists" (101). Angel Island is also included in Science Fiction and Fantasy Literature: A Checklist, 1700-1974, vol. 1 (Reginald 274).

xx. Helen L. Winslow (1851-1938) had helped founding the New England Women's Press Association. She owned and edited The Club Woman, a monthly magazine.

xxi. The famous theater producer Charles Frohman produced suffrage plays, see "In the Spotlight," Evening Star, January 14, 1912, "Theater Notes," The Washington Times, January 28, 1912. Charles Frohman wanted to produce "The Perplexed Husband," written by British playwright Alfred Sutro, which had been a success in London.

xxii. See for example "Suffrage Play Rehearsed," Evening Star (Washington, D.C.), April 27, 1913.

xxiii. Gertrude Atherton (1887-1948) was an essayist, a novelist, and a shortstory writer. She published her first narrative The Randolphs of Redwood in 1888. Her works include Patience Sparhawk (1897), Tower of Ivory (1910), California, an Intimate History, (1914), Black Oxen (1923).

xxiv. Margaret Deland (1857-1945) wrote short stories, poems and novels. Her works include John Ward, Preacher (1888), Old Chester Tales (1899), The Awakening of Helena Richie (1906), The Iron Woman (1911). She was elected to the National Institute of Arts and Letters in 1926, along with Edith Wharton.

xxv. These works included Today's Daughter by Josephine Daskam (Bacon, NY: D. Appleton \& Co., 1914), Virginia by Ellen Glasgow (New York: Doubleday, Page \& Co., 1913), Angela's Business, by Henry Sydnor Harrison (Boston: Houghton Mifflin Company, 1915), Hagar by Mary Johnston (Boston: Houghton Mifflin Company, 1913), The Honey Bee by Samuel Merwin (Indianapolis: The Bobbs-Merril Company, 1915), The Precipice by Ella W. Peattie (Boston: Houghton Mifflin Company, 1914) The Rise of Jennie Cushing by Mary S. Watts (New York: The MacMillan Company, 1914).

xxvi. Other collections of suffrage literary productions include Friedl's anthology of suffrage plays, entitled On to Victory, Crew's catalogue of suffragist sheet music. Some collections have been republished, such as Charlotte Perkins Gilman's Suffrage Songs and Verses. Scholars of the suffrage movement have done important work trying to identify and list these texts. In her dissertation, The Art of Citizenship, Maggie Amelia Rehm has included in her appendices many helpful lists of sources: suffrage theater performances, suffrage plays, ambiguous and anti-suffrage plays, poems and songs published in The Suffragist and rhymes and poems published in the "Comments of the press" section plays. Finally, websites such as Googlebooks or Internet Archives offer access to some of the suffrage literary productions. 


\section{ABSTRACTS}

This paper examines some of the ways suffragists used literature to negotiate empowerment in the context of their political campaign. The texts under scrutiny functioned as political tools on many levels: they mocked and subverted male authority, they expressed women's views, they tried to educate and galvanize supporters. They point to a belief in the power of the word to change the world, both on paper and in the streets.

\section{INDEX}

Keywords: Alice Duer Miller, Elizabeth Jordan, fiction, George Middleton, Gertrude Atherton, Helen L. Winslow, history, Inez Haynes Irwin, literature, Margaret Deland, Marietta Holley, modernism, politics, power, woman suffrage

\section{AUTHOR}

\section{CLAIRE DELAHAYE}

Université Paris-Est Marne-la-Vallée 